lefymenko, $T$.

Academy of Financial Management, 38, Druzhby Narodiv Blvd., Kyiv, 01014, Ukraine,

+380 44277 5115, afu@afu.kiev.ua

\title{
COORDINATION OF COUNTERACTION TO TURMOIL IN THE ECONOMIC SPACE OF THE BLACK SEA REGION
}

\begin{abstract}
Introduction. The scientific substantiation of the updated institutional framework for the integration of the Black Sea Economic Cooperation Organization (BSEC) countries in the context of its gradual transformation into a multilateral integration structure is an urgent issue problem of the present-day reality insofar as in new conditions, there are threatening tendencies towards disrupting the market equilibrium caused by geopolitical factors and aggravated risks of destabilization in the economic activity.

Problem Statement. The current state of the hybrid world order is accompanied by the restructuring of international, government, and civil society institutions. Manifestations of uncertainty, conflicting relationships in the Black Sea countries complicate the implementation of European integration reforms aiming at supporting the sustainable development.

Purpose. To identify the most relevant areas of required social transformations in BSEC Member States, taking into consideration the fact that the nations have independent interests in terms of possible external and internal threats and impacts. In the economic aspect, this means to ensure employment, solvency of parties to contracts, etc.

Materials and Methods. The research is based on a systematic approach, consistent processing of interrelated trends in statistical indices, situational analysis, and synthesis methods.

Results. Ways of strengthening the counteraction to destabilization of the economy of the region have been covered. Given its strategic role, it has been proposed to focus on the problems of shaping the future proceeding from the principle of coordination of BSEC scenarios and actions.

Conclusions. Collaboration between global and regional players to form a common strategic thinking should focus on funds and tools to transform the Black Sea region from a zone of confrontation into a space for the peaceful convergence of civilization values. Successive measures to reduce the territorial tensions should be adapted to relatively low rates of societies' perception of the need for compatible reforms to achieve sustainable development goals.
\end{abstract}

Keywords: economic security, sustainable development, the Black Sea region, peaceful relations, and national priorities.

The international and national security of states located within the Black Sea and Caspian basins is one of the geopolitical priorities of their strategic development programs. A specific feature of the so-called wider Black Sea area (WBSA) is that throughout the history of human civilization, it was the place of intersection of ethnical, cultural, trade and energy communications that connect the European and the Asian continents.

(c) IEFYMENKO, T., 2019
Therefore, in the context of new economic reality, it is extremely important to reinterpret the next cycles of the format and the content of the components of national competitiveness, which mostly are congruent with transformations in the power circles.

The wide internationalization of business corporations has contributed to the creation of single labor, goods, and services markets, strengthening the relations between the real sectors of na- 
tional economies, and to further integration of the financial operations environment. At the same time, unlike the coordinated integration, certain processes of globalization are characterized by uncertainty and incompleteness. That is, despite the fact that international barriers between countries are getting weaker, economic ties between them are developing unilaterally and inconsistently.

The purpose of this research is to review the current scholarly research publications, both theoretical and applied, on the specific features of the Black Sea Economic Community (BSEC) established in June 1992 and uniting 12 Member States to promote cooperation, peace, and stability in the Black Sea [1-12, 14-17, 20-28, 30, 32-33, 37]. Particular attention has been paid to the problems of the uncertainty, the probability, and the nature of new global shocks, etc. Against the background of the prospect for spreading the macro-trends of the so called national selfishness [1] inherent in the present-day national policies of the leading European and Asian countries, the United States of America, etc., the main trends of macroeconomic indicators of some countries have been outlined. These countries are chosen because of the fact that discussing the fundamental issues of the further development of the BSEC region always involves not only the countries neighboring to the European Union, but also those that do not have a direct access to the Black and Caspian seas and are located at a great distance from them like the United States, China, and others. At the same time, there remains question about the ways of eliminating the mutual uncompromising claims of the Black Sea countries within the framework of long-term contractual relations due to changes in the configurations of established interests of players at the global and regional levels, which necessitates the decision making regarding the expediency of revising the treaties and agreements, political and economic unions, etc. dated the $20^{\text {th }}$ century. Therefore, the conclusions below are based on a generalized view of well-known researchers on the impact of fundamental shifts in the global environment on the European integration processes in the context of the priorities of the sovereign states of the Black Sea region in the future, as well as on general considerations on ways for building joint programs to counteract economic destabilization in the BSEC Member States.

The dynamics of the modern hybrid world order are accompanied by the modernization of policies aiming at fulfilling the strategic objectives of the organization to counteract the external and internal threats of cyclical turning periods. The matter is the necessity to prevent the adverse synergistic influence of the inevitable universal civilizational trends and deep current changes in the conditions of the alternation of human life formations on public relations. The boundaries of the reform institutional framework shall include a gradual increase in the confidence and the sustainability of business activities of counterparties of all forms of ownership, both in the context of widened self-reproduction and with respect to the threat of destructive changes.

Therefore, the professional community generally supports the view of the International Monetary Fund (IMF) representatives that the problems of global integration tendencies are extremely relevant on a planetary scale [2]. The stability of economic and financial systems depends on the formation of effective response to the challenges caused by their imbalance within the periods of general and local recessions. It is about the development of measures by the governments and international organizations to respond to the complications associated with the post-crisis recovery of national economies, to the manifestations of instability in all components of the international and national financial environment, to an increase in the inequalities and differentiation of social strata of the population due to migration processes, as well as to the lack of quality jobs. The spatiotemporal threats of crisis phenomena, including their geopolitical aspects, shall be counteracted in updated development strategies of high-, medium- and low-income countries. 
The review of the development problems of the BSEC as one of the leading international structures, shall start with an analysis of the theoretical foundations of the modern world space dynamics, which significantly influence the regional factors of destabilization. The researches of wellknown scholars J. Stiglitz, K. Reinhart, K. Rogoff, and P. Krugman [3-5] deal with the creation of new tools for managing and controlling the processes of globalization based on the methodological framework of institutionalist, system-governing, and technological approaches. Global imbalances lead to significant changes in established contracts and in the behavior of economic agents. The leaders of the Ukrainian academic schools V.M. Geyets and B.E. Kvasnyuk have noted the stakeholders that are part to economies of individual countries, international groups, and transnational corporations are escalating rivalry, while defending their interests. Aggravating situations have been observed from time to time due to the lack of a new international economic order to solve global problems of contractual relations [6, 7]. Proceeding from this, regulatory institutions shall create mechanisms for keeping the socioeconomic, internal and external political stability of society [8]. In the conditions of intensification of integration processes, the indicators of sustainable development of society and competitiveness in the world economic system [9], taking into account the worldwide known international indices and ratings ${ }^{1}$, form the basis for evaluating the economic security, i.e. the ability of a country to counteract various destabilizing internal and external threats.

Full member of the NAS of Ukraine O.G. Belarus together with T.I. Iefymenko [10] and other

\footnotetext{
${ }^{1}$ The following international indices and ratings are used to form a system of indicators to assess the level of economic security of a country: the Global Competitiveness Index; the Index of Economic Freedom; the Global Enabling Trade Index; the Sustainable Society Index; KOF Index of Globalization; Human Development Index; World Happiness; Doing Business; the Worldwide Governance Indicators; the Democracy Index; the Corruption Perceptions Index, etc.
}

Ukrainian researchers [1, 6-10, 22, 23] have repeatedly stated that signs of global phenomena cover the economy and all spheres of social activities and affect the sources, duration, and extent of disruptions in national economies, as well as the balance of political and economic interests. At the same time, according to the IMF expert community, the current wave of globalization cannot be considered unique [11], since in the past, the intensity of movement of goods and capital flows changed rapidly as well. In addition, a relatively small portion of our planet's population has been actually involved in the current transformation processes.

The BSEC regional policy formulation in the context of globalization undoubtedly deserves considering the fundamental changes in the U.S. government policy, first and foremost, regarding the protection of corporate interests in terms of retention and increase in job places. As noted in the J. Fox Report [12], many trade deals in the United States were accompanied by a threat of reducing value-added chains in which operating activities required high professional skills. The reason for this was that workers from countries that had free access to the U.S. market initially agreed to work for low wage, but later they got trained and gained high skills through the consistent professional development. Some hazardous risks are associated with a possible decline in business of innovative corporations that depend on interaction with industry. Consequently, stagnation trends steadily spread over the research networks involved in designing new products. For similar reasons, a trade surplus in the hightech industry has degraded to a deficit [13]. In the future, there is a risk of spreading this trend over the high-quality professional services (accounting, law, data analysis, Internet management, etc.), because in the global deregulated market, any professional activity related to information technology can move to places with a cheaper labor force.

The further BSEC economic security measures shall aim at preventing the negative experience of 
radical shifts in the U.S. trade policy, which made a major contribution to aggravating gap between the worker productivity and wage in the U.S ${ }^{2}$.

The unprecedented confrontation between the world leading security guarantor, the United States, and China has resulted in trade and foreign exchange conflicts that are likely to lead to a dramatic slowdown in the global economy, as noted by the IMF Chairman Christine Lagarde at the regular meeting of G20 finance ministers and governors of central banks [14]. The growing risks as a result of escalating tension in the area of commodity exchange and in the financial sector shall be counteracted by measures that help to resolve contractual disputes through international cooperation based on innovative partnership, without taking any extraordinary actions. In this case, the role of the IMF, as one of the centers of the global financial security system, shall remain unchanged.

According to J. Schumpeter, growth in productivity is a result of gradual development and discrete upgrade of production cause-and-effect relationships and their components, which inevitably leads to the creation of effective structures in the national economy [15]. Therefore, it is no coincidence that the prominent geopolitical leaders are constantly seeking consensus. This was evidenced by the results of the bilateral meeting between the U.S. President Donald Trump and the Chairman of the European Commission Jean-Claude Juncker, in Washington, in July 2018. The parties agreed to work on abolishing the already established contractual restrictions within a newly created working group. According to the parties [16], a compromise was reached due to the EU decisions on the import of liquefied natural gas from the United States, on mutually beneficial growth in the supply of services and in the trade in chemical, pharmaceutical, and medical products, etc.

It is necessary to study the best EU practice on the most effective anti-crisis strategies to achieve

${ }^{2}$ As EPI's Productivity-Pay Tracker shows, labor productivity has increased 6.6 times, since 1973. the sustainability goals of developed socio-economic systems (SES). In Germany and France, for example, life has confirmed the validity of the postulate formulated by institutionalism theorists. According to them, an effective humane society needs two components of a hybrid system: the market and the public sector (government). Both these components are necessary for productive operation of the economy like both hands are needed for applauding [17]. Successful and competitive countries are those where the governments take the lead in creating favorable conditions for sustainable business growth. They use all available tools to achieve these goals, mainly, the fiscal and monetary leverage. The periods of accelerated economic policy modernization tend to correlate with the initiation of innovation by government political will. However, as a result of the impact of signs of new depressive waves in the leading economies (Eurozone, Brazil, India, and China) on the transition markets, it is necessary to intensify the counteraction to instability at the regional level [18] and to take consorted efforts to neutralize the factors impeding post-crisis recovery. In the future, for the economic indices of the BSEC Member States to approach those of advanced economies, governments shall use a multidimensional set of coordinated tools and measures in innovation, production, foreign trade and other fields. Given the signs of global uncertainty, the role of macroeconomic, budget, financial, monetary, and foreign exchange levers in the government anti-crisis policy shall be strengthened.

Increasing volatility and complexity of global economic relations not only aggravate uncertainty, but also complicate decision-making. Therefore, a clear understanding of common ways for addressing the global problems is needed. In 2014, a fundamental Report on Global Risks was presented in Davos [19] ${ }^{3}$. The experts conclude that

${ }^{3}$ This document based on the views of 700 experts is prepared by a group of companies specializing in risk identification and measurement (Marsh \& McLennan, Swiss Re, Zurich Insurance Group), with universities in Singapore and the UK involved. 
in the next decade, the most dangerous threats are financial crises, high unemployment, and escalation of income inequality. At the same time, macroeconomic problems remain to be main challenges to the global world. The most dangerous risks with the most pessimistic consequences are budget crisis, unemployment, lack of water, income inequality, climate change, and collapse of information systems. The most likely risks for the national economies are income inequality, extreme weather conditions, unemployment, climate change, and cyberattacks [19].

Any component of the economy, including the monetary sphere, shall be directed, first and foremost, towards the attainment of public goals: enhancing the well-being of individuals and society as a whole [20]. In this case, the well-being of individuals depends not only on the standard GDP concepts, even plus economic security, but also on a much broader set of values, including cohesion and social solidarity, trust in social, political, and democratic institutions. In the case of poor regulation, financial systems can lead to economic instability with social protests and poverty, when, as a result of crises, the problems inherent in the modern market economy are exacerbated.

While forecasting the BSEC development prospects, it is worthwhile to pay attention to the experience of territorial cooperation and the development of relevant organizational innovations in Europe. As noted by L. de Sousa [21], joint EU programs shall be based on overcoming the obstacles to institutional diversity and lack of financial autonomy in the regions. Creating and improving the established international conceptual frameworks for integration processes requires the further institutionalization of various forms of European cross-border regionalism, depending on the leadership positions of states and economic agents in political, economic, cultural, geographical spheres, on the level of ethnic identity, and so on. It is about introducing common rules to prevent threats of conflict situations by seeking consensus of interests in many spheres, in particular, when implementing large-scale infrastructure projects related to material and intellectual support for increasing the well-being of citizens with reliable sources of resources for the realization of investment intentions and the protection of property rights.

In sovereign European states, the distribution of powers and the level of autonomy of decentralized territorial units varies widely. At the same time, in any case, in terms of cooperation, the competencies and resources of municipalities, districts, and regions will remain under control of central governments. Therefore, according to the author, the upgrade of territorial management institutes shall be harmonized with the reforms of the applicable legislation and compliance procedures. In addition, the regulatory framework for transparency of the EU's institutional architecture shall be strengthened based on the coordination of relevant national laws and bylaws and supranational rules and standards. Keeping contractual relationships within a single fiscal space is essential. This enables developing and implementing universal approaches to financing the integrated structural reform programs on a sound budget basis.

O. Kushnir [22, 23] considers the activities of the BSEC Member States in fulfilling the tasks of peacekeeping and sustainable regional progress in the context of achieving common goals in the European integration area. At the same time, certain destabilizing tendencies in international relations have been reported. Firstly, it should be kept in mind that in the context of ethnic and socio-cultural diversity of the Black Sea basin, there are disparities in the paths of development of BSEC Member States, because of disproportionate size, population, military power, and differences in the chosen economic models, political system, and so on. Secondly, in the space-time aspect, there is a significant interstate tension in the region, both in retrospective and today. F. Proedrou [24] critically discusses integrative schemes and their circumscribed successes amidst a volatile pan-European security order 
and the poor prospects for 'bigemony', or shared hegemony, in the Black Sea region.

All this has traditionally led to lack of confidence, accumulation of conflicts of interest [23], in particular, concerning the use of the benefits of the transit position, including the transportation of fuel and energy resources. Additional difficulties have arisen because of the need to comply with the rules established by international organizations the BSEC Member States joined at the same time ${ }^{4}$. Therefore, according to the researcher, reliable and mutually beneficial long-term economic relations shall become the only non-conflict basis for regional cooperation within the BSEC framework. In fact, the loyalty of regional countries to this or that international institution may change the balance of power and the degree of market equilibrium at the micro and macro levels.

At the beginning of the $21^{\text {st }}$ century, Greek researcher E. Siskos [25] emphasized the necessity of transformation of BSEC post-socialist government strategies by strengthening the priorities of domestic markets development, improving the price and monetary policies, in particular, through harmonizing the national expenditures for the production of goods and services and wages to the international ones. In the same period, researcher D. Triantaphyllou [26] noted some paradoxical contradictions in the realization of the potential and the dynamics of rise of EU Member States and territorial organizations like BSEC and GUAM ${ }^{5}$. Therefore, among the factors that facilitate the further prosperity of the wider Black Sea area [27], in addition to interest in cooperation [28], there is focus on the prevention of threats of new economic realities, which aggravate as a result of dangerous consequences of the existing long-term socio-economic and political problems. Implementation of the policy instruments under the Black Sea Synergy program and the European Com-

\footnotetext{
${ }^{4}$ An important feature of BSEC is that three countries in the region are EU members and five are members of NATO.

${ }^{5}$ Organization for Democracy and Economic Development is a regional association of Georgia, Ukraine, Azerbaijan, and the Republic of Moldova.
}

mission Declaration on Public and Financial Institutions [29] describing the principles of sound financial security for long-term investments and public-private partnership is focused on addressing the abovementioned issues.

E. Vespremeanu and M. Golumbeanu [30] highlight the mission of the new associations to unite local governments for sustainable territorial governance. It is about working together for common inclusive development, creation of jobs, combatting of poverty, as well as for security, territorial unity, and democracy. The authors emphasize that the most relevant direction of economic cooperation is the innovative Blue Growth strategy that provides for smart, sustainable decisions for investing and creating added value in common marine and coastal zones, business circles [31]. The most promising sectors include the development of blue energy, blue biotechnology, extraction of marine minerals and so on. Nautical and coastal tourism in the Black Sea basin is also regarded as a priority area of cooperation [32].

Thus, for more than a quarter of a century, BSEC's activities through multilateral cooperation, dialogue, and good neighborliness have contributed to the prosperity of the region. However, the relative stability and peaceful climate within the Black Sea basin are impaired by hybrid conflicts and annexation of Crimea by the Russian Federation.

The BSEC's role in the region is getting stronger, as its strategic priorities [33] are changing while implementing the Sustainable Development Goals by sovereign actors [34], updating the environmental policies, promoting trade and investment, building transport networks and infrastructure, and combatting the organized crime and corruption. In the economic sphere, the revitalization of interaction between the BSEC and other external partners, first and foremost, with the European Union, is foreseen to be based on strengthening the trust institutions, in particular, by increasing investments with a fair distribution of risks and maximum settlement of the interests of investors of all forms of ownership. 
The purpose of the research is to substantiate the directions for strengthening the future security of the BSEC economies with their obligations under regional treaties, in particular, with respect to the commonwealth of the Black Sea countries, taken into consideration.

During the Cold War, most of the Black Sea region countries were ruled by autocratic and paternalistic regimes, and their economic systems were developing based on centralized planning principles. For known geopolitical reasons, in the late 20 th century, almost all the Black Sea region countries turned towards democratic restructuring with a transition to a market economy.

At the beginning of the $21^{\text {st }}$ century, against the EU enlargement trend accompanied with an increase in domestic demand, export-import operations, lending, and foreign direct investment, the countries showed a steady economic growth. The 2008 global financial crisis caused serious imbalances and a decline in manufacture of goods and provision of services. However, like many other transitional economies, in 2010-2018, almost all the Black Sea region countries showed signs of recovery and further stabilization of national economies. In recent years, among the factors of destabilization of the Black Sea region (geopolitical, ethnic, environmental, etc.), the most dangerous have been the synergistic problems of declining aggregate demand as a result of reducing investment and consumer expenditures, deteriorating price environment for commodities, etc.
All this required focusing the BSEC policy on the creation of a powerful capacity to replace the external factors of gradual macroeconomic dynamics by the appropriate internal countervailing measures. The quantitative characteristics of the Black Sea economies are given below.

According to IMF estimates [35], the total global growth in the emerging markets and developing countries is expected to be worsening as compared with the same quarter of 2018 [36]. GDP growth that made up $4.5 \%$, in 2018 , will decline to $4.4 \%$, in 2019 and rise to $4.8 \%$, in 2020 , which is less by $0.1-0.3$ percentage points than in the previous review. The economic growth rate in the European emerging markets (excluding CIS countries) ${ }^{6}$ is much slower than in the world in their segment: $-3.6 \%$, in $2018 ; 0.8 \%$, in 2019 ; and $2.8 \%$, in 2020 [35]. In the future, these indices will remain within the same range due to stabilizing the financial and economic environment at the external level, as well as due to growing demand for goods and services in the Eurozone. It should be noted that the analysts of the Security Program in the Black Sea Region (SBSR) [37] emphasize that, among the Black Sea countries, Turkey's economic growth forecast is somewhat better because of foreign demand and adequate government and central bank policies in terms of government credit guarantees, expectations of financial market, and necessary level of monetization of the economy, etc. (see Table). In 2017, a strong anti-crisis driver for the entire region was an increase in

\footnotetext{
${ }^{6}$ The analysis of economic trends in the development of the European region is based on data for 51 countries. According to the IMF country classification, among them there are $27^{*}$ advanced economies, $12^{* *}$ emerging market and developing economies, and $12 * * *$ CIS economies (only 4 of them are located in Europe). Turkmenistan changed its status to associate member of CIS since August 2005, Georgia left CIS since August 2009 and so did Ukraine since April 2015. However, according to IMF classification, they were included in this group of countries due to geographical location and similarity of economic structure [14, 15]. Starting with October 2019, WEO, the regional group Commonwealth of Independent States (CIS) is discontinued. Four of CIS economies (Belarus, Moldova, Russia, and Ukraine) are added to the regional group Emerging and Developing Europe.

The country classification is as follows: *Austria, Belgium, Cyprus, Czech Republic, Denmark, Estonia, Finland, France, Germany, Greece, Iceland, Ireland, Italy, Latvia, Lithuania, Luxembourg, Malta, Netherlands, Norway, Portugal, San Marino, Slovakia, Slovenia, Spain, Sweden, Switzerland and the United Kingdom; **Albania, Bosnia and Herzegovina, Bulgaria, Croatia, Hungary, Kosovo, Macedonia, Montenegro, Poland, Romania, Serbia, and Turkey, despite the fact that the majority of its territory and population is referred to Asia; ***Armenia, Azerbaijan, Belarus, Georgia, Kazakhstan, Kyrgyzstan, Moldova, Russia, Tajikistan, Turkmenistan, Ukraine, and Uzbekistan.
} 
lefymenko, $T$.

GDP Dynamics Indices

\begin{tabular}{|c|c|c|c|c|c|c|c|c|c|c|c|c|c|c|c|}
\hline \multirow{4}{*}{$\begin{array}{l}\text { Country/group } \\
\text { of countries }\end{array}$} & \multicolumn{15}{|c|}{ Period, years } \\
\hline & $\begin{array}{c}1991- \\
2000\end{array}$ & $\begin{array}{c}2001- \\
2006\end{array}$ & $\begin{array}{c}2007- \\
2009\end{array}$ & $\begin{array}{c}2010- \\
2013\end{array}$ & 2014 & 2015 & 2016 & 2017 & 2018 & 2019 & 2020 & 2021 & 2022 & 2023 & 2024 \\
\hline & \multicolumn{7}{|c|}{ Actual } & \multicolumn{2}{|c|}{ Actual/estimate } & \multicolumn{6}{|c|}{ Forecast } \\
\hline & \multicolumn{15}{|c|}{ GDP, real percentage as compared with the previous year } \\
\hline BSEC countries & -1.0 & 6.3 & 1.8 & 4.0 & 1.7 & 0.2 & 1.5 & 3.7 & 2.6 & 0.8 & 2.2 & 2.3 & 2.2 & 2.4 & 2.4 \\
\hline Azerbaijan & -2.6 & 16.3 & 15.1 & 2.8 & 2.8 & 1.1 & -3.1 & $0.1^{*}$ & $1.4^{*}$ & 3.4 & 3.1 & 2.1 & 1.6 & 1.5 & 1.7 \\
\hline Albania & 2.0 & 5.9 & 5.6 & 2.2 & 1.8 & 2.2 & 3.3 & $3.8^{*}$ & $4.2^{*}$ & 3.7 & 3.9 & 3.9 & 4.0 & 4.0 & 4.0 \\
\hline Bulgaria & -3.6 & 5.9 & 3.3 & 0.9 & 1.8 & 3.5 & 3.9 & 3.8 & $3.2^{*}$ & 3.3 & 3.0 & 2.8 & 2.8 & 2.8 & 2.8 \\
\hline Armenia & 2.9 & 12.7 & 2.2 & 4.3 & 3.6 & 3.3 & 0.3 & $7.5^{*}$ & $5.0 *$ & 4.6 & 4.5 & 4.5 & 4.5 & 4.5 & 4.5 \\
\hline Greece & 2.5 & 4.2 & -0.5 & -6.3 & 0.7 & -0.4 & -0.2 & $1.5^{*}$ & $2.1^{*}$ & 2.4 & 2.2 & 1.6 & 1.2 & 1.2 & 1.2 \\
\hline Georgia & 5.2 & 7.7 & 3.8 & 5.8 & 4.6 & 2.9 & $2.8^{*}$ & $4.8^{*}$ & $4.7^{*}$ & 4.6 & 5.0 & 5.2 & 5.2 & 5.2 & 5.2 \\
\hline Moldova & -5.7 & 6.7 & 1.6 & 5.3 & 5.0 & -0.3 & 4.4 & $4.7^{*}$ & $4.0^{*}$ & 3.5 & 3.8 & 3.8 & 3.8 & 3.8 & 3.8 \\
\hline Russia & -2.1 & 6.5 & 2.0 & 3.8 & 0.7 & -2.5 & 0.3 & $1.6^{*}$ & $2.3^{*}$ & 1.6 & 1.7 & 1.7 & 1.6 & 1.6 & 1.6 \\
\hline Romania & -1.4 & 6.1 & 3.6 & 0.9 & 3.4 & 3.9 & 4.8 & 7.0 & $4.1^{*}$ & 3.1 & 3.0 & 3.0 & 3.0 & 3.0 & 3.0 \\
\hline Serbia & -2.2 & 6.8 & 3.1 & 1.2 & -1.6 & 1.8 & 3.3 & $2.0^{*}$ & $4.4^{*}$ & 3.5 & 4.0 & 4.0 & 4.0 & 4.0 & 4.0 \\
\hline Turkey & 3.8 & 5.3 & 0.4 & 8.2 & 5.2 & 6.1 & 3.2 & 7.4 & $2.6^{*}$ & -2.5 & 2.5 & 3.0 & 3.0 & 3.5 & 3.5 \\
\hline Ukraine & -7.7 & 7.1 & -1.6 & 2.4 & -6.6 & -9.8 & 2.4 & 2.5 & 3.3 & 2.7 & 3.0 & 3.1 & 3.2 & 3.3 & 3.3 \\
\hline $\begin{array}{l}\text { European emer- } \\
\text { ging markets and }\end{array}$ & & & & & & & & & & & & & & & \\
\hline CIS countries & -0.7 & 6.2 & 2.5 & 4.3 & 2.2 & 1.0 & 1.9 & 4.0 & 3.2 & 1.6 & 2.5 & 2.6 & 2.5 & 2.7 & 2.7 \\
\hline
\end{tabular}

* IMF estimates and preliminary data.

Based on World Economic Outlook Database. 2019. April. URL: https://www.imf.org/external/pubs/ft/weo/2019/01/ weodata/index.aspx.

trade flows from and to CIS counterparts, as well as migrants' remittances from places of temporary employment to their countries of residence.

In 2018, the total economic growth in the CIS countries was $2.8 \%$; in 2019 , it will decrease to $2.2 \%$. In the medium term, it will stabilize at $2.3-$ $2.4 \%$. Because of the lower dynamics of the CIS economies, if this group of countries [38, 39] (with emerging markets) is included in the IMF analytical approaches to the total indices of the European region for 24 countries, the total output growth is estimated at about $3.2 \%$, in $2018,1.6 \%$, in 2019 , and $2.5-2.7 \%$ in the medium term (see Table) $)^{7}$.
The Table shows that within the period under review, the GDP dynamics of individual BSEC countries (actual/estimate 1991-2018, forecast 2019-2024) differed from the general trends in the organization.

In 1991-2018, according to the actual data, in addition to Ukraine, the minimum indices in different years were reported for Greece $(+4.2 \%$, in 2001-2006, and $-6.3 \%$, in 2010-2013) and for Azerbaijan. ( $-3.1 \%$, in 2016, and $+0.1 \%$, in 2017). Georgia $(+5.2 \%$, in 1991-2000), Azerbaijan $(+16.3 \%$, in $2001-2006$, and $+15.1 \%$, in $2007-$ $2009)$, and Turkey $(+8.2,+5.2$, and $+6.1 \%$, in $2010-$ 2013,2014 , and 2015, respectively) had the high-

\footnotetext{
${ }^{7}$ Aggregated group scores are defined as weighted average by group. For real GDP, the GDP is weighted by purchasing power parity (PPP) (at current prices, USD billion), and GDP per capita is weighted by the actual population (see the IMF website for detailed methodology: URL: https://www.imf.Org/external/pubs/ft/weo/faq.htm\#q4f)
} 


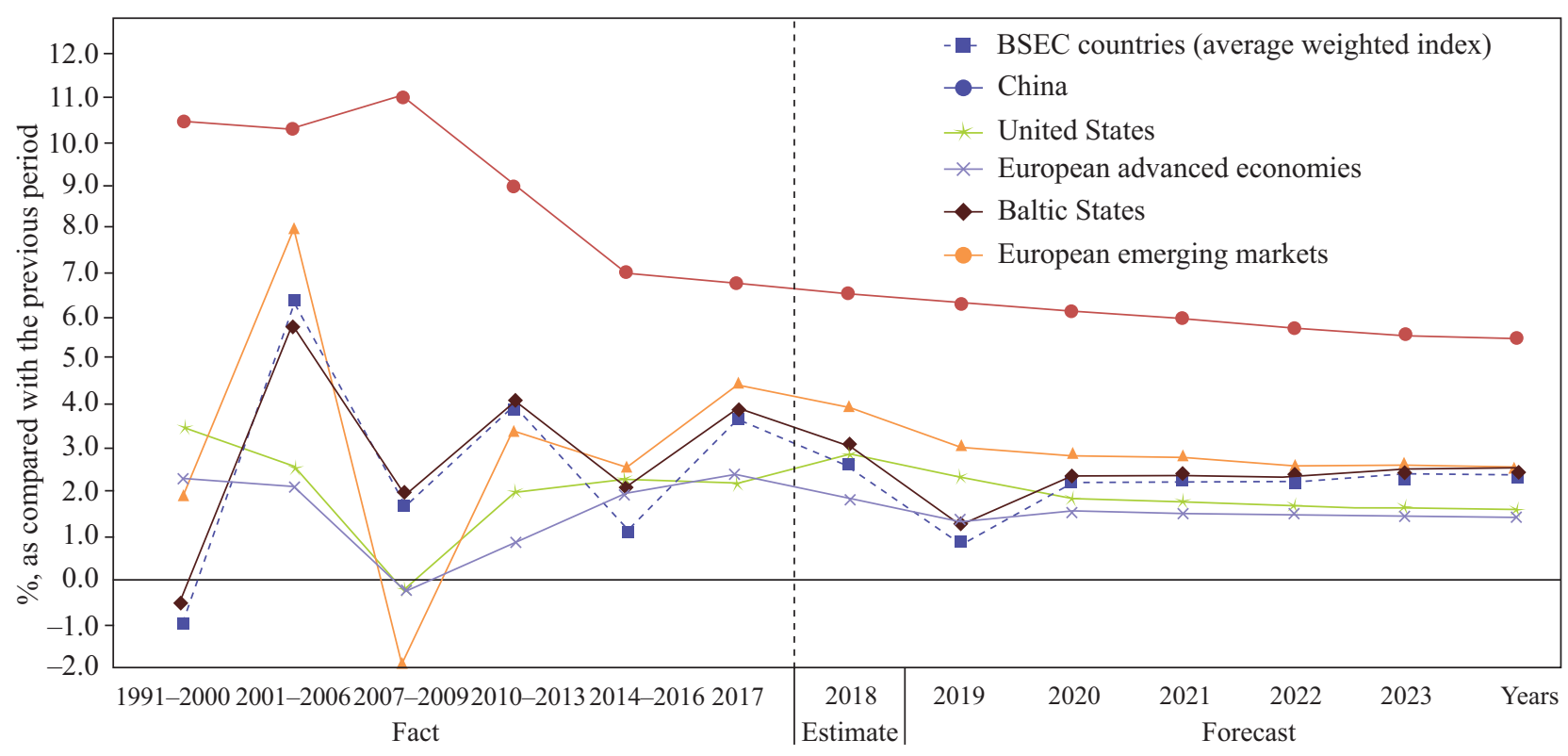

Fig. 1. Real GDP growth, \% as compared with the previous yeara

Based on World Economic Outlook Database. 2019. April. URL: https://www.imf.org/external/pubs/ft/weo/2019/01/ weodata/weoselgr.aspx (last access 11.07.2019).

est indices in the reported period. The leader were Romania, in 2016, (+4.8\%) and Armenia, in 2017 and $2018(+7.5 \%$ and $5.0 \%$, respectively).

GDP in the BSEC countries is expected to grow more steadily in 2019-2022, according to the forecast data, which all are in the positive segment. In the period under review, the annual GDP growth in Ukraine is higher (2.7-3.3\%) than the BSEC average. The leaders will be Armenia (4.6\%, in 2019, and 4.5\%, in 2020-2024), Georgia (4.6\%, in 2019, and 5.2\%, in 2020-2024), while the outsiders will the Russian Federation (+1.6-1.7\%, in 2019-2024) and Greece (2.2-2.4\%, in 2019-2020 and 1.2-1.6\%, in 2021-2024).

Main concerns about the Black Sea region security are largely driven by the strategic importance of its role as one of the world leading energy producers and suppliers. Energy supply routes run through the countries of the region, forming the so-called energy corridor between the Caspian Sea and the world markets. Therefore, there is no doubt that the export of natural energy resources and refined products will remain the traditional priorities for stimulating the growth of energy suppliers in the long run. A relatively new trend, which has been observed in all Black Sea countries, is an increase in the share of services in the total output, with noticeable changes in its structure in favor of private ownership. Among the risks for the sustainable development in the Black Sea region there are a relatively low level of value added in the real economy. In general, the degree of riskiness of the business environment in the BSEC countries depends, to a large extent, on the coordination of institutional levers in the sphere of contractual relations. The matter is the necessity to respond jointly to the threats of new economic reality, which provoke disparities in rules and regulations and disproportion of the formal and the informal sectors of the economy, which, in its turn, leads to dependence on unpredictable crisis phenomena of chaotic origin.

Analytical data on the annual real GDP growth in the BSEC countries (weighted average by the organization) as compared with other countries are shown in Fig. 1. 


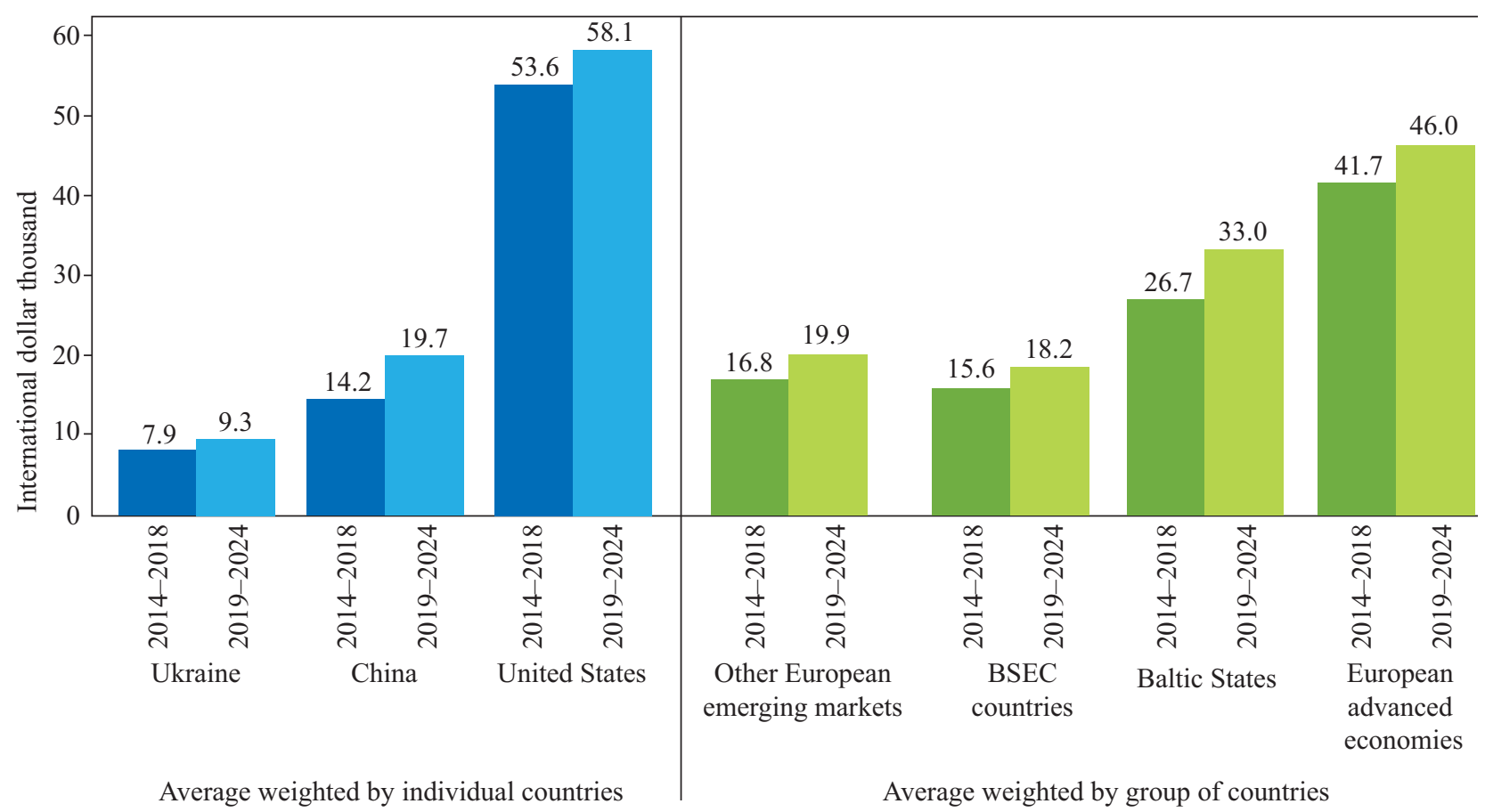

Fig. 2. Average GDP per capita weighted by PPP in 2014-2018 and in 2019-2024 (in fixed prices), international dollar thousand

Based on World Economic Outlook Database. 2019. April. URL: https://www.imf.org/external/pubs/ft/weo/2019/01/ weodata/weoselgr.aspx (last access 11.07.2019) and the UN, DataCenter. URL: http://unctadstat.unctad.org/EN/Index. html (last access 11.07.2019).

The trends in Fig. 1 show that within the period under review, fluctuations in the average weighted GDP dynamics in the BSEC countries are close to those of the European emerging markets and the Baltic States. In the period of the institutional formation (1991-2000), the averaged weighted dynamics of GDP in the BSEC countries were negative, whereas the Baltic States showed positive dynamics $(+1.9 \%)$. In the advanced economies of Europe $(-0.3 \%)$ and the USA $(-0.4 \%)$, a significant decrease of this index (a negative growth) was observed only in 2007-2009. During the same period, there was recorded a decline $(-1.9 \%)$ in the Baltic States. According to the forecast for 2019-2024, the indices of all individual countries, except for China, and their groups will range within $+1.5-2.5 \%$. China's economy was steadily growing over 2001-2018, with a minimal increase of $+6.6 \%$, in 2018 . It is noteworthy that during the crisis of 2007-2009 it reached its maximum level of $+11.0 \%$. The forecast also shows its dominant advantage over other economies $(+5.5-+6.3)$. These data indicate a successful economic development of the People's Republic of China, one of the world leaders in utilizing the potential opportunities to participate in global production chains characterized by long-term investment in innovation. China's experience in implementing economic growth policies, which has confirmed that technological breakthroughs, along with the modernization of the real economy are the key drivers of the new industrial revolution is of utmost importance for the BSEC. That means, it is necessary to unite the efforts of all the Black Sea countries towards making structural transformation, building the necessary infrastructure, and attracting funding. Modern investors are interested not only in the rapid organization of new production, but also in a clear focus on meeting the demand of certain market 


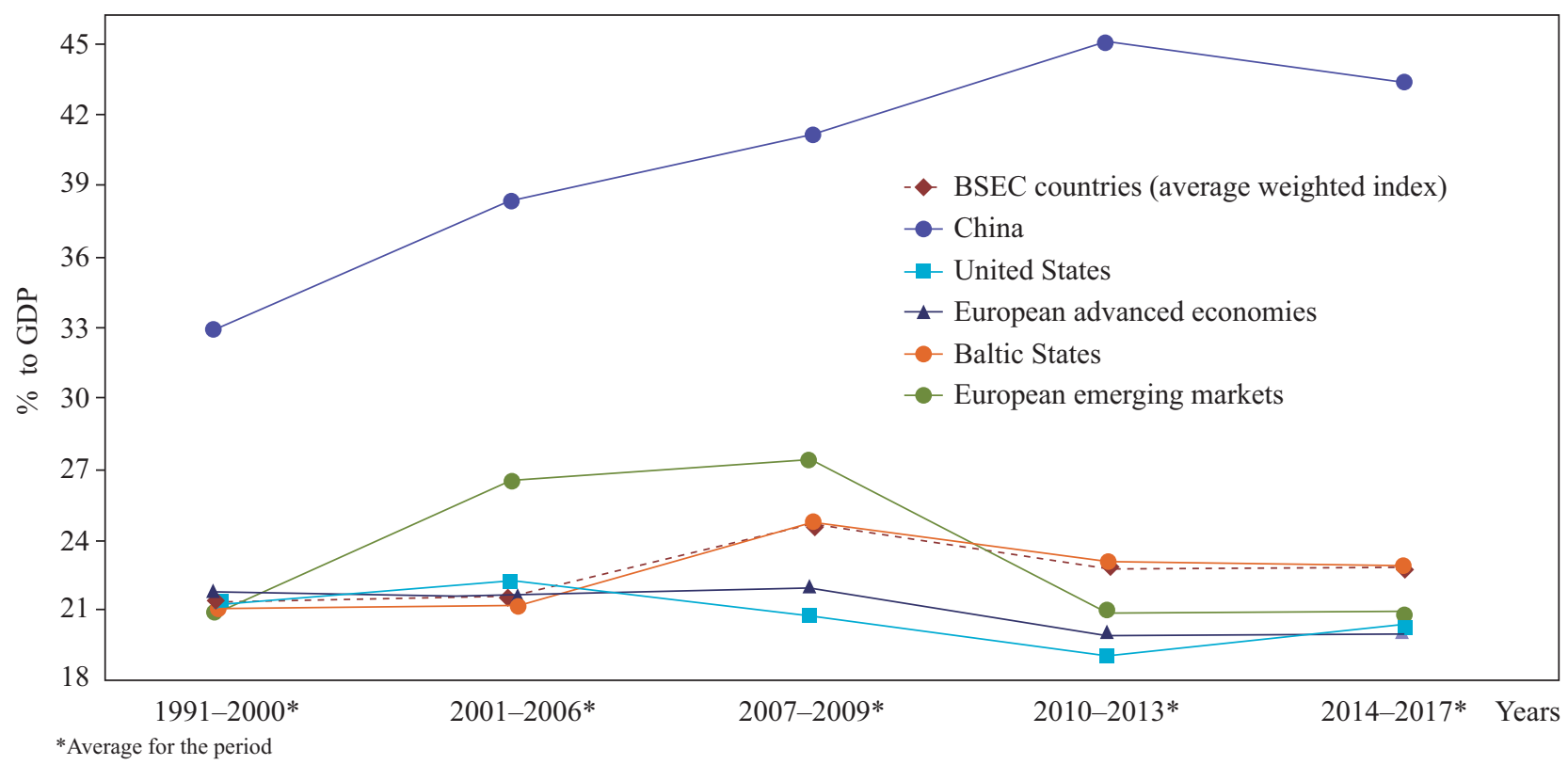

Fig. 3. Share of GFCF in GDP, in 1991-2017, \% of GDP

Based on the UN, DataCenter. URL: http://unctadstat.unctad.org/EN/Index.html (last access 11.07.2019).

niches. The upgraded regulative mechanisms of the governments shall provide for not only an increase in income and GDP per capita, but also the development of human capital, education and health care, and combatting of social inequality.

The analysis has shown that in the BSEC countries, the disparities in the people wellbeing formed in the past because of different demographic situation and the level of economic development have remained. However, in the future, the humanity will be united by the goals of sustainable inclusive economic development. Their characteristics are given in many international documents $[34,40,41]$. The world community has concluded that the living standard of population depends not only and not so much on income or GDP dynamics. The actual and forecasted dynamics of GDP per capita, with PPP taken into consideration, in 2014-2018 and in 2019-2024, respectively, are given below (Fig. 2).

The BSEC GDP per capita weighted by PPP is slightly lower than that of other European emerging markets and will remain much lower than that of the advanced economies of Europe, the Baltic States, the United States, and China. Due to a high economic growth, this index in China is expected to exceed the average one in the BSEC countries as early as in 2019 and, by 2024, the gap will reach $15 \%$, despite the fact that 25 years ago, this China's index was $4-5$ times less than that of the Black Sea region countries. Among the BSEC countries, the minimum GDP per capita weighted by PPP is reported for Ukraine, Moldova, Armenia, and Albania. According to the forecast, by 2024, it will reach about 10,000 international dollars in Ukraine and Moldova, while the highest index of 25,000 - 29,000 international dollars is expected for Turkey, Romania, Greece, etc.

The development of activities that help the BSEC countries overcome the gap with the world leaders and many European advanced economies is in the focus of both the government bodies, the professional community, and the business entities. The BSEC countries need to consistently implement modern human rights protection, social security and environment standards. The development of competition and entrepreneurship 
should not prevent the fair distribution of benefits from increased productivity. To this end, both governments as well as businesses shall ensure a high level of integrity, transparency, and accountability. As a rule, in transitional economies, as a result of unequal access to the labor and capital markets, women, young people or elderly experience problems with employment and doing business. The income inequality and unemployment are exacerbated by distrust in the government and its fiscal policies, damage social contract, and lead to aggravation of social stratification. Therefore, the coordination of prospective plans for accelerating the development of BSEC countries shall be backed by increasing pace of national economic growth, cessation of the personnel brain drain, reduction in the corruption level, in order to make them advanced economies with a high level of investment activity and savings of economic agents of all forms of ownership, in the future.

One of the main tasks of structural reforms in the BSEC countries is to create conditions for attracting domestic and foreign investment in high value-added production. Changes in the share of gross fixed capital formation (GFCF) in GDP for 1991-2017 are shown in Fig. 3. In the long run, its quantitative targeting should aim at a significant steady increase up to, at least, $25 \%^{8}$. That is, the real investments shall increase by, at least, one third as compared with the present level. As the world experience shows, expectations for stable growth in the context of dynamic and inclusive development in the long run are generally not met if the share of final consumption in GDP reaches 85-90\% (it is typical for Albania, Armenia, Greece, Georgia, and Ukraine, in 2009-2018). For example, in China, since 1992, the share of GFCF in GDP has not dropped below $30 \%$, showing an averaging of $43 \%$, in 2014-2017, with the respective share of final consumption accounting for $52 \%$ [42]. The factors of financial and economic sustai-

${ }^{8}$ The analytical calculations are made in collaboration with researchers of the Academy of Financial Management.

nability being organically interdependent, the strategic tasks of BSEC countries at the regional and national levels are as follows: to increase investment costs for direct or loan or guarantee support of human capital, innovation, and business development, etc.; to avoid imbalances and desynchronization in production and circulation of goods and money, as well as imbalances in the interests of business and society. Joint investment projects in the energy and transport infrastructure shall be initiated in the BSEC countries, which contributes to better agglomeration of the region. The flows of production and monetary assets, both real and virtual, shall be coordinated towards achieving the sustainable development goals, as agreed between the governments and the public, settling the contradictions of productive forces and industrial relations, and eliminating the material, monetary, information, and other manifestations of inequality.

Despite the difficult situation, recent developments in the BSEC have shown positive trends in institutional transformations aiming at increasing competitiveness and inclusiveness. In the near future, taking into account the best world practices, it is necessary to make decisions on simplifying business doing in order to create more attractive conditions to entrepreneurs in the sphere of privatization, investment and intellectual property protection. The creation of new integration forms, norms, and rules for the interaction between the BSEC and the European Union shall be synchronized with political transformations and contribute to the economic benefits of investing in the medium and long term. The development of innovative mechanisms for government-business cooperation, structural reforms that affect the enhancement of competitiveness and resource productivity will contribute to counteracting the threats to post-crisis economic recovery in the conditions of destabilizing uncertainties [43]. It should be well understood that, in the future, WBSA will require interstate and national forecasting of the internal and external risks for economic sustainability. 
The economic growth and further reduction in the tension in the Black Sea region will largely depend on the extent to which the European integration processes, in individual BSEC countries and in the entire region, contribute to creating the single market within the WBSA, making and fulfilling multilateral trans-border agreements. In any case, removing trade barriers, increasing labor mobility, and intensifying investment flows will help to level the economic potential of individual regions and municipalities, as well as the living standards of the population. However, in our view, the most predictable scenario of the development of the Black Sea region is evolutionary transformations.

Thus, the long-standing problems of tense relations are periodically exacerbated by factors of uneven political and socio-economic development of the Black Sea region countries. However, it is obvious that the problems shall be solved amicably by means of diplomacy, with clear strategic development goals and ways for achieving them. The Euroscepticism trends and Brexit initiative have graphically shown the need to continue the structural institutional transformations of the EU to overcome the crisis.

While developing a coherent economic policy for the sovereign states of the Black Sea region, it should be kept in mind that the international community focuses its attention towards the in- terstate regulation of capital concentration and centralization, as well as of the activities of multinational corporations and financial intermediaries. The harmonization of international and national economic and political interests requires the elimination of contradictions in the laws of the member states who set common goals for global development and develop universal mechanisms for their implementation, taking into account differences in the national economic policies.

To make the accelerated modernization of economic policy more successful it shall be part of government innovation efforts. Accessibility and efficiency of use of financial and other types of resources determine the successful achievement of the goals.

The factors of financial and economic sustainability being organically interdependent, the strategic task of BSEC countries at the regional and national levels is to avoid imbalances and desynchronization in production and circulation of goods and money, as well as imbalances in the interests of business and society. The flows of production and monetary assets, both real and virtual, shall be coordinated towards achieving the sustainable development goals, as agreed between the governments and the public, settling the contradictions of productive forces and industrial relations, and eliminating the material, monetary, information, and other manifestations of inequality.

\section{REFERENCES}

1. Horbulin, V. (2018, June 15). Volcanic syndrome. URL: https://dt.ua/internal/vulkanichniy-sindrom-280772_html [in Ukrainian] (Last accessed: 12.07.2019).

2. IMF. (2017, September). Finance \& Development. URL: http://www.imf.org/external/pubs/ft/fandd/2017/09/ pdf/fd0917.pdf (Last accessed: 12.07.2019).

3. Stiglitz, J. E. (2010). The Stiglitz Report: Reforming the International Monetary and Financial Systems in the Wake of the Global Crisis. New York: New Press.

4. Reinhart, C. M., Rogoff, K. (2011). This Time Is Different: Eight Centuries of Financial Folly. New York.

5. Krugman, P. (2009). The Return of Depression Economics and the Crisis of 2008. New York: W. W. Norton \& Company.

6. Heiets, V. M. (2003). Threats to the Development of the National Economy and Their Avoidance. Economy of Ukraine: Strategy and Policy of Long-Term Development. Kyiv: NASU Institute for Economics and Forecasting: Phoenix 136-154 [in Ukrainian].

7. Heiets, V. M., Kvasniuk, B. E. (1999). Concept of economic security of Ukraine. Kyiv: Logos [in Ukrainian].

8. Heiets, V. M. (Ed.). (2006). Modeling of economic security: state, region, enterprise. Kharkiv: INZHEK [in Ukrainian].

9 Kyzym, M. O., Ivanov, Y. B., Hubarieva, I. O. (2018). Evaluation of the level of economic security of Ukraine and EU countries. Finanse of Ukraine, 4, 7-19 [in Ukrainian]. 
10. Bilorus, O. H., Iefymenko, T. I. (Ed.). (2015). Financial globalization and European integration, 13-29. Kyiv: SESE "The Academy of Financial Management" [in Ukrainian].

11. Tanzi, V. (2005). Social Protection in a Globalizing World. URL: http://www.rivistapoliticaeconomica.it/2005/ mar-apr/Tanzi.pdf (Last accessed: 12.07.2019).

12. Faux, J. (2016, November 30). U.S. Trade Policy - Time to Start Over (Report). URL: https://www.epi.org/ publication/u-s-trade-policy-time-to-start-over/ (Last accessed: 12.07.2019).

13. U.S. International Trade Commission (USITC). (n. d.). USITC Interactive Tariff and Trade DataWeb. URL: https://dataweb.usitc.gov/scripts/user_set.asp (Last accessed: 12.07.2019).

14. IMF. (2018, July). Statement by the IMF's Managing Director on the G20 Finance Ministers and Central Bank Governors meeting in Argentina. URL: http://www.imf.org/en/News/Articles/2018/07/22/pr18302-argentina-statementby-the-imf-managing-director-on-the-g20-meetings (Last accessed: 12.07.2019).

15. Schumpeter, J. A. (2011). The theory of economic development: an inquiry into profits, capital, credit, interest, and the business cycle. Kyiv: Kyiv-Mohyla Academy [in Ukrainian].

16. Embling, D. (2018, July 26). EU breathes sign of relief over transatlantic trade row. URL: http://www.euronews. com/2018/07/26/eu-breathes-sign-of-relief-over-transatlantic-trade-row (Last accessed: 12.07.2019).

17. Samuelson, P., Nordhaus, W. (1998). Economics (16 ${ }^{\text {th }}$ ed.). Boston, MA: Irwin/McGraw-Hill.

18. United Nations. (2012). World Economic Situation and Prospects 2012. New York. URL: http://www.un.org/en/ development/desa/policy/wesp/wesp_archive/2012wespupdate_pr_en.pdf (Last accessed: 12.07.2019).

19. World Economic Forum. (2016). The Global Risks Report 2016. URL: http://www3.weforum.org/docs/GRR/ WEF_GRR16.pdf (Last accessed: 12.07.2019).

20. Stiglitz, J. E. (2016). The Euro. How common currency threatens the future of Europe. New York.

21. De Sousa, L. (2012, August). Understanding European Cross-border Cooperation: A Framework for Analysis. JournalofEuropeanIntegration,1-19.URL:http://repositorio.ul.pt/bitstream/10451/6856/1/ICs_LSousa_Understanding_ ARI.pdf (Last accessed: 12.07.2019).

22. Kushnir, O. (2017). Ukrainian policies in the Black Sea littoral: history, current trends and perspectives. Journal of Contemporary European Studies, 25(2), 163-179. doi: /10.1080/14782804.2016.1219845.

23. Kushnir, O. (2014). From the BSU to the BSEC: Evaluating Interwar Geopolitical Fantasies. The Central European Journal of International and Security Studies, 8(4), 90-111 [in Ukrainian].

24. Proedrou, P. (2018, May). In quest of governance: the failures of regionalism, a pan-European security architecture and 'bigemony' in Black Sea Politics. Journal Southeast European and Black Sea Studies, 18(3), 439-456.

25. Siskos, E. (2004, December). Export-biased growth and problems of domestic market in post-socialist countries of the Black sea economic cooperation. Journal of European Economy, 3(4), 374-387.

26. Triantaphyllou, D. (2009). The 'security paradoxes' of the Black Sea region. Journal of Southeast European and Black Sea Studies, 9(3), 225-241. doi: 10.1080/14683850902934143.

27. Hajizada, M., Marciacq, F. (2013). New regionalism in Europe's Black Sea Region: The EU, BSEC and changing practices of regionalism. East European Politics, 29(3), 305-327.

28. Hajizada, M. (2018). Challenges and opportunities for establishing a security community in the wider Black Sea area. Journal of Southeast European and Black Sea Studies, 18(4), 529-548.

29. European Commission. (2017). Sustainable Blue Economy Finance Principles. URL: https://ec.europa.eu/maritimeaffairs/befp_en .

30. Vespremeanu, E., Golumbeanu, M. (2017, November). International Cooperation in the Black Sea Basin. The Black Sea, 125-133. doi: 10.1007/978-3-319-70855-3_10.

32. Stanciulescu, G. C., Molnar, E. I. (2018). European implication in tourism regarding Sustainable development around the Black sea. International Multidisciplinary Scientific Conference on Social Sciences EArts SGEM, 5, 275-282. URL: https://www.sgemsocial.org/ (Last accessed: 12.07.2019).

33. Chiţiba, C. A. (2016). Black Sea Economic Cooperation Organization Short and Medium Term Prospects. Knoweledge Horizons - Economics, 8(1), 14-17.

34. United Nations. (2015, October 21). Transforming our world: the 2030 Agenda for Sustainable Development. URL: https://sustainabledevelopment.un.org/post2015/transformingourworld (Last accessed: 12.07.2019).

35. IMF (2018, October). World Economic Outlook. Challenges to Steady Growth. URL: https://www.imf.org/en/ Publications/WEO/Issues/2018/09/24/world-economic-outlook-october-2018 (Last accessed: 12.07.2019).

36. IMF (2019, April). World Economic Outlook. Growth Slowdown, Precarious Recovery. URL: https://www.imf. org/en/Publications/WEO/Issues/2019/03/28/world-economic-outlook-april-2019 (Last accessed: 12.07.2019). 
37. Harvard University, "Mihai Viteazul” National Intelligence Academy, Administraţia Prezidenţială. (2018). SBSR. Security in the Black Sea Region. Shared Challenges, Sustainable Future Program. Bucharest, May 28-31, 2018. URL: http://www.sbsr.ro/wp-content/uploads/2018/06/SBSR-2018-Outcome.pdf/ (Last accessed: 12.07.2019).

38. IMF. (2018, April). World Economic Outlook Database. URL:http://www.imf.org/external/pubs/ft/weo/2018/01/ weodata/weoselgr.aspx (Last accessed: 12.07.2019).

39. IMF. (2015, April). World Economic Outlook Database. URL: http://www.imf.org/en/Publications/WEO/ Issues/2016/12/31/Uneven-Growth-Short-and-Long-Term-Factors (Last accessed: 12.07.2019).

40. OECD. (2015). New Approaches to Economic Challenges: A sustainable and inclusive growth agenda: OECD Yearbook 2015. URL: www.oecd.org/naec (Last accessed: 12.07.2019).

41. OECD. (2018). The Framework for Policy Action on Inclusive Growth. Paris, 30-31 May 2018. URL: https://www. oecd.org/mcm/documents/C-MIN-2018-5-EN.pdf (Last accessed: 12.07.2019).

42. UNCTAD. (n. d.). Data Center. URL: http://unctadstat.unctad.org/EN/Index.html (Last accessed: 12.07.2019).

43. Iefymenko, T. (2016). Fiscal and Monetary Security of National Economy. Kyiv: SESE "The Academy of Financial Management" [in Ukrainian].

Received 18.01.19

Revised 18.02.19

Accepted 21.02.19

\section{T.I. Єфименко}

Державна навчально-наукова установа «Академія фінансового управління», бульв. Дружби народів, 38, Київ, 01014, Україна, +380442775115, afu@afu.kiev.ua

\section{КООРДИНАЦІЯ ПРОТИДІЇ ПРОЦЕСАМ ДЕСТАБІЛІЗАЦІЇ В ЕКОНОМІЧНОМУ ПРОСТОРІ ЧОРНОМОРСЬКОГО РЕГІОНУ}

Вступ. Наукове обгрунтування оновлених інституціональних засад об'єднання держав Організації Чорноморського економічного співробітництва (ОЧЕС) у контексті поступового iï перетворення на багатосторонню інтеграційну структуру є актуальним питанням сьогодення, оскільки в умовах нової реальності спостерігаються загрозливі тенденції порушення ринкової рівноваги внаслідок геополітичних чинників, посилення ризиків дестабілізації в просторі господарської діяльності.

Проблематика. Сучасний стан гібридного світоустрою супроводжується перебудовою міжнародних, державних і суспільних інститутів. Прояви невизначеності, конфліктні взаємовідносини у країнах Причорномор'я ускладнюють проведення євроінтеграційних реформ, спрямованих на підтримку сталого розвитку.

Мета. Ідентифікувати найсуттєвіші напрями необхідних суспільних перетворень в країнах ОЧЕС з урахуванням незалежності інтересів націй щодо можливих зовнішніх і внутрішніх загроз та впливів. В економічному аспекті насамперед ідеться про забезпечення зайнятості, платоспроможності учасників контрактних відносин тощо.

Матеріали й методи. Для аналізу використано системний підхід, послідовна обробка взаємопов'язаних трендів статистичних індексів, методи ситуаційного аналізу та синтезу.

Результати. Розкрито шляхи зміцнення протидії дестабілізації економіки регіону. 3 урахуванням його стратегічної ролі запропоновано зосередитися на проблемах формування майбутнього, з огляду на принцип скоординованості сценаріїв та дій країн ОЧЕС.

Висновки. Співпраця глобальних і регіональних гравців, спрямована на формування спільного стратегічного мислення, повинна фокусуватися на пошуку коштів та інструментів для перетворення Чорного моря із зони конфронтації на простір для мирної конвергенції цінностей цивілізації. Послідовні заходи щодо зниження територіальної напруженості варто гармонізувати з порівняно невисокими темпами сприйняття суспільствами потреби в сумісних реформах для реалізації цілей сталого розвитку.

Ключові слова: економічна безпека, сталий розвиток, Чорноморський регіон, мирні відносини, національні пріоритети. 


\section{Т.И. Ефименко \\ Государственное учебно-научное учреждение «Академия финансового управления», бульв. Дружбы народов, 38, Киев, 01014, Украина, +380442775115, afu@afu.kiev.ua \\ КООРДИНАЦИЯ ПРОТИВОДЕЙСТВИЯ ПРОЦЕССАМ ДЕСТАБИЛИЗАЦИИ В ЭКОНОМИЧЕСКОМ ПРОСТРАНСТВЕ ЧЕРНОМОРСКОГО РЕГИОНА}

Введение. Научное обоснование обновленных институциональных основ объединения государств Организации Черноморского экономического сотрудничества (ОЧЭС) в контексте постепенного ее превращения в многостороннюю интеграционную структуру является актуальным вопросом настоящего времени, поскольку в условиях новой реальности наблюдаются угрожающие тенденции нарушения рыночного равновесия вследствие геополитических факторов, усиление рисков дестабилизации в пространстве хозяйственной деятельности.

Проблематика. Современное состояние гибридного мироустройства сопровождается перестройкой международных, государственных и общественных институтов. Проявления неопределенности, конфликтные взаимоотношения в странах Причерноморья затрудняют проведение евроинтеграционных реформ, направленных на поддержку устойчивого развития.

Цель. Идентифицировать наиболее существенные направления необходимых общественных преобразований в странах ОЧЭС с учетом независимости интересов наций по отношению к возможным внешним и внутренним угрозам и влияниям. В экономическом аспекте, прежде всего, речь идет об обеспечении занятости, платежеспособности участников контрактных отношений и т. п.

Материалы и методы. Для анализа использованы системный подход, последовательная обработка взаимосвязанных трендов статистических индексов, методы ситуационного анализа и синтеза.

Результаты. Раскрыты пути укрепления противодействия дестабилизации экономики региона. С учетом его стратегической роли предложено сосредоточиться на проблемах формирования будущего, учитывая принцип скоординированности сценариев и действий стран ОЧЭС.

Выводы. Сотрудничество глобальных и региональных игроков, направленное на формирование общего стратегического мышления, должно фокусироваться на поиске средств и инструментов для преобразования Черного моря из зоны конфронтации в пространство для мирной конвергенции ценностей цивилизации. Последовательные меры по снижению территориальной напряженности стоит гармонизировать со сравнительно невысокими темпами восприятия обществами потребности в совместных реформах для реализации целей устойчивого развития.

Ключевые слова: экономическая безопасность, устойчивое развитие, Черноморский регион, мирные отношения, национальные приоритеты. 